\title{
The Implementation of Classroom Management Principles in Teaching English at Vocational High School 3 Padang
}

\author{
Suparmi \\ Universitas Putra Indonesia YPTK Padang, Indonesia \\ mimiesuparmi7@gmail.com
}

\begin{abstract}
The aim of this research was to find out how the teachers implemented principles of classroom management in teaching and learning process at SMKN 3 Padang during teaching and learning process. This is a qualitative research. The data were the result of observation and interview. The participants of this research were three English teachers of SMKN 3 Padang who teach at grade X, XI and XII. The finding of this research indicates that English teachers at SMKN 3 Padang do not implement almost all of the principles of classroom managements during teaching and learning process. They implemented them in three stages of teaching; such as pre-activity, whilst-activity and post activity. Almost all of the principles of classroom management are implemented in whilst-activity. At pre and post-activity, the teacher only implemented three principles, such as warm and enthusiasm, emphasizing on the positive things and building self-discipline. Moreover, the data shows the teachers' reasons in implementing classroom management. The reason is increasing students' motivation and achievement. It can be concluded that the English teachers at SMKN 3 Padang should improve their focuses to the principles of classroom management in teaching English. Hopeful, this research can be a significant contribution for English teachers in teaching.
\end{abstract}

Keywords: Classroom Management, Classroom Management Principles

\section{Introduction}

Classroom management refers to sequence of activities for creating and protecting the optimal condition of teaching and learning process. Therefore, a teacher needs to understand the basic concept of classroom management since all of its roles have to be done well in order to create an effective teaching and learning process.

Moreover, learning process will not run effectively if there is a gap happens in classroom. It affects the students' interest to learn and breaks the teacher's teaching plans that have been prepared before. This condition forces the teacher to be able to transform back that condition to be conducive one at that time. Briefly, the roles of teacher are very needed in managing the classroom in order to achieve the purpose of teaching itself and provide the students with effective learning atmosphere, in short, they can participate well during teaching and learning process.In addition, the aims of classroom management are not only includes all of the activities in the classroom, but also can be the facility for all of students' learning activities in the classroom. That facility is defined as an ideal classroom condition, which serves the students effective and interesting learning activities. By considering the purpose of the classroom management, it is clear that the roles of the teacher are considered as the principles of classroom management.

Furthermore, classroom management process cannot run well if the teacher cannot implement all of the principles of classroom management. This study focused on principles of classroom management stated by Williams (2000:7) such as warm and enthusiasm, challenge, variation, flexiblelity, emphasizing on the positive thing and building self-discipline. All of those principles must be understood and implemented by teachers in teaching learning process. Classroom management cannot stand without those principles because each of principles will contribute directly toward process of classroom management itself. In this case, teachers needto have a good comprehension about all of those principles in order to do a good classroom management during teaching and learning process. 


\section{Research Method}

A qualitative research was used since it was aimed to how the principles of classroom management implemented by the English teachers in teaching and learning process at SMKN 3 Padang. The sources of the data were the result of observation of implementation of classroom management principles during teaching and learning process on English subject at SMKN 3 Padang. It is also worth noting that the information about the research participants in this research was gathered at a single point in time. The subjects of this study were 3 English teachers of SMKN 3 Padang.

\section{Result and Discussion}

Table Of Classroom Observation

\begin{tabular}{|c|c|c|c|c|c|c|c|c|c|c|c|}
\hline \multirow[t]{3}{*}{ Variable } & \multicolumn{11}{|c|}{ IndicatorSub IndicatorFinding } \\
\hline & & & \multicolumn{3}{|c|}{$\begin{array}{l}\text { Teacher } \\
\text { One }\end{array}$} & \multicolumn{3}{|c|}{$\begin{array}{l}\text { Teacher } \\
\text { Two }\end{array}$} & \multicolumn{3}{|c|}{ TeacherThree } \\
\hline & & & 1 & 2 & 3 & 1 & 2 & 3 & 1 & 2 & 3 \\
\hline \multirow{15}{*}{\begin{tabular}{|l|} 
Principles \\
of \\
Classroo \\
m \\
Managem \\
ent
\end{tabular}} & \multirow[t]{4}{*}{\begin{tabular}{|l} 
Warm \\
and \\
Enthusi \\
asm
\end{tabular}} & $\begin{array}{l}\text { Building } \\
\text { Good } \\
\text { Relation } \\
\text { ship }\end{array}$ & $\mathrm{V}$ & $\mathrm{V}$ & $\mathrm{V}$ & $\mathrm{V}$ & V & $\mathrm{V}$ & $\mathrm{V}$ & $\mathrm{V}$ & V \\
\hline & & $\begin{array}{l}\text { Vocal } \\
\text { Delivery }\end{array}$ & $\mathrm{V}$ & $\mathrm{V}$ & $\mathrm{V}$ & $\mathrm{V}$ & & $\mathrm{V}$ & $\mathrm{V}$ & $\mathrm{V}$ & $\mathrm{V}$ \\
\hline & & Eye Contact & - & $\mathrm{V}$ & $\mathrm{V}$ & $\mathrm{V}$ & $\mathrm{V}$ & $\mathrm{V}$ & $\mathrm{V}$ & $\mathrm{V}$ & V \\
\hline & & Gesture & $\mathrm{V}$ & $\mathrm{V}$ & $\mathrm{V}$ & V & $\mathrm{V}$ & $\mathrm{V}$ & $\mathrm{V}$ & $\mathrm{V}$ & V \\
\hline & $\begin{array}{l}\text { Challen } \\
\text { ge }\end{array}$ & Giving Task & - & - & $\mathrm{V}$ & $\mathrm{V}$ & $\mathrm{V}$ & $\mathrm{V}$ & $\mathrm{V}$ & $\mathrm{V}$ & V \\
\hline & \multirow[t]{7}{*}{$\begin{array}{l}\text { Variatio } \\
\mathrm{n}\end{array}$} & \multirow{3}{*}{$\begin{array}{l}\text { Variati } \\
\text { on of } \\
\text { Teachi } \\
\text { ng } \\
\text { Style: } \\
\text { 1. Teacher- } \\
\text { Centere } \\
\text { d } \\
\text { Classroo } \\
\text { m } \\
\text { 2. Student- } \\
\text { Centere } \\
\text { d } \\
\text { Classroo } \\
\text { m }\end{array}$} & & & & & & & & & \\
\hline & & & $\mathrm{V}$ & V & - & - & - & - & - & - & - \\
\hline & & & - & - & $\mathrm{V}$ & $\bar{V}$ & & $\mathrm{~V}$ & $\mathrm{~V}$ & $\mathrm{~V}$ & $\mathrm{~V}$ \\
\hline & & $\begin{array}{l}\text { Variation of } \\
\text { UsingMedia }\end{array}$ & - & - & - & $\mathrm{V}$ & & $\mathrm{V}$ & - & - & - \\
\hline & & $\begin{array}{l}\text { Variation of } \\
\text { Interaction }\end{array}$ & & & & & & & & & \\
\hline & & $\begin{array}{l}\text { Students } \\
\text { Interacti }\end{array}$ & $\mathrm{V}$ & V & - & - & & - & - & - & - \\
\hline & & $\begin{array}{l}\text { on } \\
\text { 2. Students } \\
- \\
\text { Students } \\
\text { Interacti } \\
\text { on }\end{array}$ & - & - & $\mathrm{V}$ & $\mathrm{V}$ & - & $\mathrm{V}$ & $\mathrm{V}$ & $\mathrm{V}$ & $\mathrm{V}$ \\
\hline & \multirow[t]{2}{*}{$\begin{array}{l}\text { Flexibili } \\
\text { ty }\end{array}$} & $\begin{array}{l}\text { Democratic } \\
\text { Teachers }\end{array}$ & $\mathrm{V}$ & $\mathrm{V}$ & $\mathrm{V}$ & $\bar{V}$ & & $\mathrm{~V}$ & $\mathrm{~V}$ & $\mathrm{~V}$ & $\mathrm{~V}$ \\
\hline & & $\begin{array}{l}\text { Responsive } \\
\text { teachers }\end{array}$ & $\mathrm{V}$ & $\mathrm{V}$ & $\mathrm{V}$ & $\mathrm{V}$ & & $\mathrm{V}$ & $\mathrm{V}$ & $\mathrm{V}$ & $\mathrm{V}$ \\
\hline & $\begin{array}{l}\text { Emphas } \\
\text { izingon }\end{array}$ & $\begin{array}{l}\text { Guide the } \\
\text { Students to }\end{array}$ & $\mathrm{V}$ & $\mathrm{V}$ & $\mathrm{V}$ & $\bar{V}$ & & $\mathrm{~V}$ & $\mathrm{~V}$ & $\mathrm{~V}$ & $\mathrm{~V}$ \\
\hline
\end{tabular}

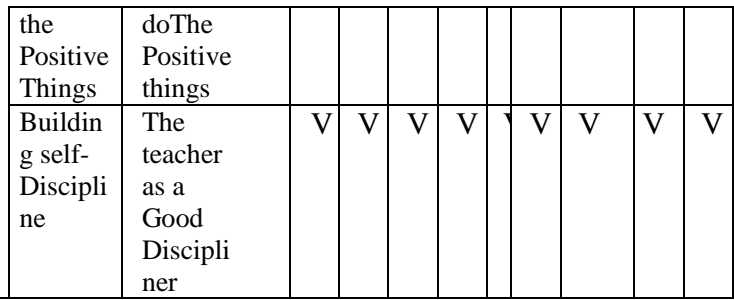

Based on the research findings above, the finding of the research explained beow:

\section{The Implementation of Classroom Management Principles of English Teacher in Teaching English at SMKN 3 Padang}

The English teachers required to teach English by implementing the principles of classroom management which consist of warm and enthusiasm, challenge, variation, flexibility, emphasizing on the positive things and building self-discipline. Based on the observation toward three English teachers at SMKN 3 Padang in implementing classroom management principles in teaching English, the researcher would like todescribe how the teachers implemented classroom management principles in teaching and learning process. This part described how the teachers implemented classroom management principles in teaching and learning process based on the stages of teaching. Furthermore, there are three stages in teaching such as preactivity, whilst-activity and post-activity. In preactivity the researcher found that the English teachers implemented some principles of classroom management at the beginning of teaching, such as warm and enthusiasm, emphasizing on the positive things and building self- discipline. At the beginning of teaching, all English teachers have implemented those principles of classroom management.

Moreover, in whilst activity the researcher found that the English teachers implemented all the principles of classroom management during teaching and learning process, such as warm and enthusiasm, challenge, variation, flexibility, emphasizing on the positive things and building self-discipline. In this stage the teachers have implemented all the principles of classroom management during teaching and learning process. Then, in the post activity the researcher found that the English teachers implemented some principles of classroom management at the end of teaching process, such as warm and enthusiasm, emphasizing on the positive things and building self- discipline. Sometimes the teacher did not implemented emphasizing on the positive things at the end of teaching process, they just leave the classroom.Based on the explanation above, it can be concluded that all the English teachers implemented all the principles of classroom management at whilst-activity. However at pre and post-activity the teachers implemented only three principles of classroom management, such as warm and

Lesson Journal: Languange, Applied Linguistics, and Education Journal Vol .3 Issue 1 (2021) 13-17 
enthusiasm, emphasizing on the positive things and teaching and learning process. They looked at the building self-discipline. It can be indicated that students' directly. The data shown that during teaching principles of classroom management commonly applied and learning process the teacher had full attention to the on whilst-activity. All English teachers implemented students. The teacher looked at to the students when almost all principles of classroom management during they communicate each other's. It is supported by Atta teaching and learning process.

Each principle of classroom management are discussed below:

\section{a. Warm and Enthusiasm}

This principle of classroom management was implemented by all English teachers in teaching and learning process. This principle divided into four sub principles, namely building good relationship, vocal delivery, eye contact and gestures. Furthermore, there were three English teachers who had been observed. They had those characteristics of enthusiasm teachers in teaching. The data shown that every teacher had built their relationship with their students, clear vocal delivery in teaching, used eye contact and appropriate gestures during teaching and learning process.

\section{1) Building Good Relationship} and Ayaz (2014:91), teachers use eye contact when they look directly at student eyes. During teaching in the classroom teachers focus their attention on their notes, points, hints or textbook but not to students, it means they lose their control on the class. Eye contact aware the students that the teacher knows what they are doing.

Relating to eye contact, as Emery (2000:27) states that a teacher should break eye contact every 5 seconds by looking up or to the side (not down) in the classroom. A teacher can also use the "triangle method," which involves looking at one eye for about 5 seconds, then the other eye for 5 seconds. If a teacher is speaking to a group, be carefulto spread his eye contact around the classroom. Before starting new sentence a teacher should focus his eyes contact on someone. In teaching learning process when making eyecontact, a good rule of thumb is to look away briefly (up or to the side) This sub principle of classroom management had been every five seconds, in this way concentration, implemented by all of English teachers. In teaching and discipline and interest can be developed within the learning process, every teacher built relationship with students.

their students. They paid attention to the students, care, and respect with all their students in the classroom and they also always give positive response to the students. When the teacher and students had positive relationship the situation in the class more conducive and the students enjoying study in the classroom. It is Supported by Pianta (2001: 54) that positive teacherstudent relationships are high in closeness like mutual respect, caring, and warmth between teachers and students.

\section{2) Vocal Delivery}

Based on the data got from the field, it can be seen that the teacher had good vocal delivery during teaching and learning process. The teacher voice could be heard by the whole class. In explaining the materials, the teacher had clear pronunciations, intonation, articulation, etc. When the teacher explained the material in front of theclass, all of the students could hear clearly what the teacher talked about. The students also understand with the topic explained by the teachers. According to Kauchack (1994:457) vocal delivery includes components of speech delivery that relate to the voice. These include rate, volume, pitch, articulation, pronunciation, and fluency. The voice is important to consider when delivering the materials in teaching and learning process for two main reasons. First, vocal delivery can help the teachers engage and interest the students. Second, vocal delivery helps ensure that teacher ideas are communicated clearly.

\section{a)Gestures}

Gesture is a movement part of the body, especially a hand or the head, to express an idea or meaning. In teaching and learning process teachers used appropriate gestures to transmit their minds and show their feelings. Related to the observation, the teacher used gesture to help the students understand with the teacher talk about without transfer the meaning into the mother tongue. It means that gesture can help the teacher in teaching and help the students in understanding the difficult word utterance by the teachers during teaching and learning process. Supported by Muramoto (1999:232), states that teachers can use specific gestures for error correction to provide students with an opportunity to self-correct. It means that the teachers used gestured to help the students in understanding the topic. However, the students can make their self-correction by seeing teachers' gestures. For example, the teachers put their hand behind their ear as if they could not hear what the student had said and thereby providing the student with an opportunity to make another attempt. According to Darn (2005: 11), gestures can reduce unnecessary teacher talking time and increase learner participation. In addition, gestures reduce fear of silence, make teachers' instructions clear and help the teacher in classroom management.

\section{3) Eye Contact}

b. Challenge

Based on the data got from the field, it can be seen that This classroom management principle was done by all the teacher had implemented eye contact during the teachers being observed. During teaching and 
learning process they challenged to their students especially in doing tasks. All teachers had same way in giving the task for the students. After they gave the task to the students, they asked their students to answer the questions by them calling the names of the students randomly to come in front of the class or to answer the questions or to do the tasks.

It is in line with the Blitar (2013:93) who states that the kind of classroom management challenges that do in learning process is in describing the task, the teacher appoint students randomly to do the task. It means that the students did not know when they will appoint by the teacher, all of them done the task well. Related to the theory fromBlitar above, it can be seen from the data that the teacher called the name of students randomly for doing the task. The aimed is to make sure all the students ready to do the task.

\section{a. Variation}

Variation in teaching English was implemented by all English teachers. This indicator divided into three sub indicators, such as variation in teaching style, variation in using media and variation of interaction. Here, it would be discussed in every sub indicator as follow:

1) Variation in Teaching Style

Teaching styles is the way of teachers in explaining the materials to the students. Every teacher had different style in teaching. There are three English teachers observed, there are two teachers used students-centered classroom in teaching and learning process they are teacher two and teacher three. Here, they just as a facilitator and students more active in the classroom. They explain the material based on the students questions only. They do the explanation until the students understand with the topic discussed. While another teacher used students centered in teaching and learning process, she is teacher one. Here the teacher as a main source of knowledge in teaching. It can be seen that the teacher explained the topic until the students understand. In overall all the teachers has same aim in teaching, to make the students understand the topic discussed. There are some characteristics of good teacher argue by Khamis (1993:98), a good teacher explains the topic well until the students understand, makes lessons enjoyable, has sense of humor and control the class well. It means that a good teacher is not only good in explaining the materials but also has sense of humor and controls the class well. a good teacher will pay attention to what the students do in the classroom during teaching and learning process to make sure that all of the students follow the lesson.

\section{2) Variation in Using Media}

In teaching and learning process, the teacher should consider the appropriate media based on the topic. Related to the data from three teachers, there is only one teacher that used variation media in teaching and learning process. She used text book, power point and also video.

However, the other teachers only used text book as a media during teaching and learning process. The teachers just explain the material based on the text book. Williams (2000:60) argues that variation of media includes three components of media such as audio, visual and tactile. In three times of observation the teacher used different media in each meeting. She was selected the media based on the purpose of learning, based on the material, etc.

In addition, the teacher also should be able to select the media based on the purpose of the topic discussed. It is supported by Imran (2014:22) there some characteristics in choosing the media in teaching and learning process such as, fit to the purpose of learning, easy to use, quality and practical and flexible. It other words, before the teacher use the media the teacher should be considered with the characteristics of media above. The media should be appropriate with the purpose of learning, the teacher should know how the media is use, the teacher also should consider about the quality of media, then, the media also should make the students interest, easy to use and simple.

\section{Variation of Interaction}

Based on three times observation with three English teachers, it can be seen that during teaching and learning process the students more active in the classroom. The teachers always give positive respond to the students when they asked something. In building the classroom interaction, the teacher posed the students by giving some questions, then after the students respond the questions the teacher give feedback.

In addition, during teaching and learning process teacher one and teacher two tend to used teacherstudents interaction in the classroom. The students accepted knowledge and information from the teacher during teaching and learning process. The teacher controlled and monitored all the students done in the classroom and give feedback to the students who asked the questions to them. However, teacher's three used students-students interaction in teaching and learning process. Here, the students more active in the classroom. The students had more participation during learning process; they share their ideas to another friends and teacher. The teacher give contribution to what they had discussed with their friends, the teacher also guides them when they make a mistake. It is supported by Ibrahim (2012:18), Successful teachers support their students to participate effectively in classroom discussions and appreciate their contributions and achievements. It means that the 
good teacher will create the good interaction in the classroom during teaching and learning process.

\section{b. Flexibility}

This classroom management principle was done by all English teachers in teaching English. The data shown that all teachers' guided the students when they faced difficulties during teaching and learning process. The teachers see, hear and respond all the problems and learning difficulties. The teachers regarded the students as their partners in teaching. The teacher give the pleasant place for the students, to make the students interested to study with their. Then, the teachers were also warm and very friendly with the students. She helped the students when they faced some difficulties in doing the task.

Flexible teacher are the teacher who can reduce any kind of students' misbehavior, such as; students make noise, students do not give their attention to the material, and the students who ignore the exercise in the classroom. Then, the characteristics of flexible teachers are having democratic and responsive behavior in teaching. It is supported by Fryer (1996:51) who state that there are two characteristics of flexibility of the teachers such as the democratic behavior and tolerance to the students, responsive to the class (want to see, hear and respond all the discipline problems and learning difficulties), and looking at the students as partners in teaching and learning process.

\section{c. Emphasizing on the Positive Things}

This principle of classroom management was done by all English teachers during teaching and learning process. The data shown that all the English teacher emphasize the students to do the positive things in the classroom. They warned the students who make noise in the classroom, they give advice to the students who did not finish their homework, and then they also remind the students to be a good people in daily. The teachers had controlled what the students do in the classroom during teachingand learning process.

Furthermore, According to William (2000: 76), the teachers should give encouragement students to do the positive things and avoid the negative things. Teachers have to control what the students do in the classroom. It means that, in teaching and learning process the teacher also should pay attention in all students' activates in the classroom. The teacher should know all that happened in the classroom during teaching and learning process.

\section{d. Building Self-discipline}

This indicator had implemented by all English teachers during teaching and learning process. In developing student's self-discipline, the teachers should be a model in the classroom. Based on the data from the field, all the English teachers have selfdiscipline in the classroom. They always come to class on time, and then all the students wait the teacher in the classroom. In addition, during teaching and learning process there were nobody up and down in the classroom, they follow the lessons well. Then, the teacher very consistent with the rules they made, who did not allow the rules they cannot follow the learning process. The teacher also reminds the students who lack of respect to them. They warned the students to respect each other. Furthermore, Moosa (2015:25) states that teachers may use harsh language, threat students to complete their work on time and criticize students, which may lead to less class participation or behavior problem among students. It means that the teacher have to control all the students activities in the classroom during teaching and learning process. In the other words, lack of respect for teachers is one of the main causes of discipline problems in the classroom. When students are asked to do something in class, they protest, and refuse to carry out the instruction.

\section{Conclusion}

There are three stages in teaching such as pre-activity, whilst-activity and post- activity. In pre-activity, the researcher found that the English teachers implemented some principles of classroom management at the beginning of teaching, such as warm and enthusiasm, emphasizing on the positive things and building self-discipline. At the beginning of teaching, all English teachers have implemented those principles of classroommanagement.

Moreover, in whilst activity the researcher found that the English teachers implemented all the principles of classroom management during teaching and learning process, such as warm and enthusiasm, challenge, variation, flexibility, emphasizing on the positive things and building self-discipline. In this stage, the teachers have implemented all the principles of classroom management during teaching and learning process.

\section{References}

[1] Arends, Richard I. 2007. Learning to Teach. New York: McGraw-Hill Company, Inc.

[2] Blitar, D.C. Effective classroom management and instruction: A knowledge base for consultation. a. Washington, DC: 2013. National Association of School Psychologists.

[3] Fryer, M. Creative teaching and learning. London. 1996: Paul Chapman.

[4] Golkar, Rasol, Aghahoseyni, Taghi, Zarrin, Ameneh, the Discipline Solutions and Techniques in the Classroom: Approaches, Models, and Perspectives: 2008. Kankash Publictions.

[5] Kauchak, Donald P and Paul D.Eggan. Learning and Teaching. Boston. 2002: McGraw-Hill Company,Inc.

[6] Kauchak, Donald P and Paul D.Eggan. Educational Psycholgy: Classroom Connections. New York: 1994.

[7] Macmillan College Publishing Company.

[8] Moosa, M.S. Discipline- Improving Classroom Management through Action Research: A Professional Development Plan: 2015. Hamdard University, Karachi.

[9] Williams, Eric Sr. Everything Classroom Management Book. United States. 2000: F+W Media, Inc. 